\title{
Social Capital at Municipal Concerts in Istanbul
}

\section{Jane Harrison}

Since the 1950s, several Istanbul district governments have offered their residents the fantastic service of free or very cheap concerts featuring professional musicians. A large and growing body of research in many fields has established that human music making is a technology that both presents and represents social structure, ${ }^{1}$ and in combination with powerful emotional outcomes. Thus it can be highly useful for doing work on groups of people, either of an integrative or divisive nature. We investigated the municipal concerts in one of the most culturally vibrant districts of Istanbul as a case study for how live music experiences can affect the social fabric in modern cities. The government is offering all residents the chance to experience the transformative power of live music, but what are the concrete outcomes in social terms of that service? A study about music and society can easily fall into vague speculations and celebrations about music's power. To avoid this pitfall we chose a guiding concept, social capital, which has a large amount of previous research behind it. Since there is a scholarly consensus that social capital is important for the functioning of human civilizations, we pinpointed and gathered data on ecologically valid mechanisms by which social capital can be created, maintained, strengthened, or diminished at the concerts. ${ }^{2}$

\section{Theoretical Basis}

\subsection{Social Capital Theory and Turkey}

Social capital is a concept that seems intuitively true and important but is notoriously difficult to define. Some scholars have emphasized trust among strangers as the crux of social capital, but that kind of trust is a culturally determined behavior. In contrast, Harmut Esser's formulation is broad and flexible, applicable to many different kinds of societies: social capital is "all those resources that an actor can mobilize and/or profit from because of his embeddedness in

1 Theo Van Leeuwen, Speech, Music, Sound (London: Macmillan, 1999).

2 Sincere thanks goes to Mustafa Kemal Özkül, Farhan Khalid, and especially Yusuf Seven for their assistance in gathering the survey data for this project. 
a network of relations with other actors." ${ }^{3}$ According to him, there are two main types. Relational capital consists of personal ties that people can use to acquire information, skills, emotional support, or some kind of access to fulfill specific needs. System capital is the shared sense of trust and goodwill within largescale social systems, encompassing generalized trust in the system and other people, and a shared set of moral norms. ${ }^{4}$ The two types address the functioning of society in two different and crucial dimensions. Like many other scholars, Esser ties social capital to trust in government; while we did gather data about government trust at the Üsküdar concerts, it will not be presented here but in another, forthcoming article.

Relational capital has especially strong roots in Turkey, where enduring, close relationships are essential for economic, social, and psychological well being. The Turkish word akraba designates a primary social unit in all of the traditional cultures of the country. Its three legal degrees encompass all blood and marriage relations extending out to second cousins, and in everyday language it also refers to very close non-family friends, especially those from one's ancestral village or neighborhood. ${ }^{5}$ A person's akraba can be a source of identity, financial help, and other kinds of resources in times of hardship; the larger and more loyal this network is, the better it functions. ${ }^{6}$ In accord with this research, in the most recent World Values Survey of Turkey (2011), a striking 95.4\% of respondents stated that family was "very important" to them and $93.7 \%$ reported complete trust in their family. ${ }^{7}$

Over the last 50 years, several million people have migrated from rural areas of the country to cities like Istanbul, mostly through the gradual chain migration of large family units. ${ }^{8}$ Scholars disagree about the extent to which traditional family interdependence has persisted in urban areas. Some find its continuance in what they term "functional extended family," even though family members might live in various corners of the city. ${ }^{9}$ Others posit that due to socioeconomic development, Turkish families are still emotionally interdependent but becoming more

3 Harmut Esser, "The two meanings of social capital," in The Handbook of Social Capital, ed. D. Castiglione, Van Deth, J. W., \& G. Wolleb (Oxford: Oxford University Press, 2008), 23-25.

Ibid., 38.

5 Şevket Ökten, "Aşiret, akrabalık ve sosyal dayanışma: geleneksel hayatı yönetme biçimi," Aile ve Toplum 11, no. 5 (2009): 99.

6 Bernhard Nauck and Daniela Klaus, "Families in Turkey," in eds. B.N. Adams and J. Trost, Handbook of World Families, 364-388 (Los Angeles: Sage, 2005), 379.

7 World Values Survey Association, WORLD VALUES SURVEY, Wave 6, 2010-2014, “Turkey,” from OFFICIAL AGGREGATE, v.20150418 [aggregate data file], last revised 2011, www. worldvaluessurvey.org.

8 Nauck and Klaus, “Families in Turkey,” 380-381.

9 Ibid., 381-383. 
financially and materially independent. ${ }^{10}$ We wondered which of these theories about family relations in Istanbul would be better born out by the concert data.

The few studies that have looked at empirical evidence of how social capital functions specifically in Turkey have emphasized thick ties and particularized trust over generalized trust. In their examination of the differences in social capital forms between Western and Eastern Europe, Fidrmuc and Gerxhani found that newer and prospective E.U. member states like Turkey tend to be more collectivist and hierarchical than those of Western Europe. ${ }^{11}$ These societies have more government corruption and unregulated economic transactions, low generalized trust, and low civic participation. They also found that Turkish people rely heavily on social networks involving family members and people of the same cultural identity to solve problems cooperatively. ${ }^{12}$ In their measures of social capital, Turkey ranks low in participation in "Putnam group" organizations like voluntary art classes that Putnam argued could promote broad social cooperation and generalized trust. ${ }^{13}$ Olson groups like unions, which promote political solidarity, have a comparatively stronger presence in the country. In their comparative case study of trust in Istanbul and Moscow, Secor and O'Loughlin sought to avoid the ethnocentric bias that certain types of trust or social capital (namely generalized trust) are inherently more valuable than others. ${ }^{14}$ For Istanbul, they found widespread distrust of local and higher government, distrust of social organizations, and high trust in family and close friends. Instead of a general trust of people in their city or in the government, residents emphasized a localized trust in their neighborhoods (mahalle). The massive urban renewal projects that have been completed in Istanbul since the time of these surveys have surely disrupted some of the traditional neighborhoods, but in many parts of the city strong bonds and trust still operate at the neighborhood level.

Particularized and thick ties in the forms of akraba and mahalle networks clearly sustain the social fabric of Istanbul. At the same time, the modern Turkish state has been striving for a century towards democratic governing mechanisms at multiple levels of society, which cannot be achieved without strong system capital. Citizens must trust in and want to play their part in civic life and democratic processes. Putnam has argued convincingly that democracies need activities that

${ }^{10}$ Boris Mayer et al., "Family models of independence/interdependence and their intergenerational similarity in Germany, Turkey, and India," Family Science 3, no. 1 (2012): 64.

${ }^{11}$ Jan Fidrmuc and Klarita Gërxhani, "Mind the gap! Social capital, East and West," Journal of Comparative Economics 36, no. 2 (2008): 268, 282.

${ }^{12}$ Ibid., 267.

13 Ibid., 270.

${ }^{14}$ Anna Secor and John O'Loughlin, "Social and political trust in Istanbul and Moscow: A comparative analysis of individual and neighbourhood effects," Transactions of the Institute of British Geographers, New Series 30, no. 1 (2005): 69-70. 
bring strangers into meaningful interaction with one another. ${ }^{15}$ The Yamagishis' notion of generalized trust ("trust in most people") has also received significant attention as it relates to the health of democracies. ${ }^{16}$ Particularly relevant to Turkey's collectivist culture is evidence that strong thick ties tend to be inversely correlated to an individual's propensity to seek social exposure among new people and to behave in trusting ways towards strangers. ${ }^{17}$ In addition to their role in underpinning governing systems, a sense of general trust and community spirit are practically helpful to living in a huge metropolis like Istanbul, where residents must interact with large numbers of strangers outside of their homes on a daily basis, including the millions of Syrian refugees that have come into the city in recent years.

\subsection{Potential Musical Mechanisms for Social Capital}

Musical experience fits into a discussion of social capital because it can function as a significant input into any of the multiple emotional systems of the human nervous system. ${ }^{18}$ This includes musical sound's regulation of the hippocampuscentered system, which is involved in social attachment and memory, by affecting oxytocin and cortisol levels. ${ }^{19}$ Overy and Molnar-Szakacs argue that music making is especially adapted to empathetic states at the level of neurophysiology, ${ }^{20}$ and experimental studies show that both short-term and long-term musical interaction can strengthen empathetic personality traits. ${ }^{21}$ Is it not as though music is a stimulus that induces emotions in people. Rather, music possesses a remarkable potential for "semiotic snowballing", as Turino terms it. As people's brains and bodies interact with musical sound in a specific context, emotional

15 Robert Putnam, Bowling Alone: The Collapse and Revival of American Community (New York: Simon and Schuster, 2000).

${ }_{16}$ Toshio Yamagishi and Midori Yamagishi, “Trust and commitment in the United States and Japan," Motivation and Emotion 18, no. 2 (1994): 129.

${ }^{17}$ John Ermisch and Diego Gambetta, "Do strong family ties inhibit trust?" Journal of Economic Behavior and Organization 75 (2010): 365.

18 Stefan Koelsch et al., "The quartet theory of emotions: an integrative and neurofunctional model," Physics of Life Reviews 13 (2015): 8, 16.

19 Stefan Koelsch, "Brain correlates of music-evoked emotions," National Revierws Neuroscience 15 (2014): 170.

${ }^{20}$ Kate Overy and Ivan Molnar-Szacs, "Being together in time: musical experience and the mirror neuron system," Music Perception 26, no. 5 (2009): 489.

${ }^{21}$ Tai-Chen Rabinowitch, "Synchronization-a musical substrate for positive social interaction and empathy," in ed. E. King, Music and Empathy, 89 (Burlington, VT: Ashgate, 2017); and Eric Clarke, Tia DeNora, and Johanna Vuoskoski, "Music, empathy and cultural understanding," Physics of Life Reviews 15 (2015): 61. 
valences bind to many signs, including those of a social nature like group identities. ${ }^{22}$ Studies about musical experience and precise social outcomes are numerous, including the increase in trust and cooperation following group singing, ${ }^{23}$ increased oxytocin levels following musical exposure, ${ }^{24}$ and the many case studies where specific groups of people use music to build feelings of solidarity and distinguish themselves from other groups. ${ }^{25}$

\subsection{The Üsküdar Concerts Context}

Due to its flexible definition, social capital needs to be elaborated in terms of the micro-mechanisms functioning in a specific context to be meaningfully observed. ${ }^{26}$ The context of the Üsküdar concerts in 2015-2016, when data was gathered, will therefore be described in some detail. All of the concerts in the municipality's seven cultural centers (kültür merkezi) are free of charge. Data was collected at the two centers that most frequently held concerts, Bağlarbaş1 (pronounced like $b a b-l a r-b a-s h u b$ ) and Altunizade. Bağlarbaşı functions as the flagship public cultural space in Üsküdar, with a spacious Ottoman-inspired design containing four large salons, two exhibition areas, an indoor café, and a large outdoor courtyard. It hosts a huge variety of art, musical, theater, and scholarly events, and important government functions. Concerts occur there as often as four times a week, usually in the largest hall with a 740-seat capacity. While Bağlarbaşı is located in a central and very busy area of Üsküdar district, Altunizade Kültür Merkezi is in a quieter neighborhood. It is likewise much smaller, has plainer architecture, and features a single hall with around 250 seats. Smaller ensembles that play türk sanat müziği (Turkish art music) and tasavvuf müziği (Islamic music) are mostly programmed there. Both cultural centers are in safe locations, easily accessible with public transportation, and advertised well on social media and on the streets. The security guards, greeters, and other staff in both cultural centers are visible, professional, helpful, and friendly to the guests.

22 Thomas Turino, Music as Social Life: The Politics of Participation (Chicago: University of Chicago Press, 2008), 108.

23 Anat Anshel and David Kipper, "The influence of group singing on trust and cooperation," Journal of Music Therapy 25, no. 3 (1988): 145.

${ }^{24}$ Mona Lisa Chanda and David Levitin, "The neurochemistry of music," Trends in Cognitive Science 17 (2013): 188-189.

25 See for example Joshua Penman and Judith Becker, "Religious ecstatics, 'deep listeners,' and musical emotion," Empirical Musicology Review 4, no. 2 (2009): 49; and Diana Miller, "Gender, field, and habitus: how gendered dispositions reproduce fields of cultural reproduction," Sociological Forum 31, no. 2 (2016): 330.

${ }^{26}$ Dario Castiglione, "Introduction: conceptual issues in social capital theory," in The Handbook of Social Capital, ed. D. Castiglione, J. Van Deth, and G. Wolleb, 13-21, (Oxford: Oxford University Press, 2008), 15. 
Concerts typically last around 90 minutes without intermission. A significant portion of the audience arrived well before the standard start time of 20:00, and sizeable groups of people would often wait outside the hall after the concert to greet the performers.

Event scheduling mostly occurs through performers' applications to use the stages, allowing the cultural centers' concerts to vary in many respects. At the same time, Üsküdar's program can be called consistently conservative. Song lyrics and other on-stage discourse were typically appropriate for families with children and steered clear of controversial issues. The concert schedule relies heavily on the professional state music ensembles, which tend to play a relatively stable, institutionalized, nationalistic literature. In interviews from 2015, culture ministry officials spoke of a desire to broaden their audiences' cultural horizons by including some concerts of European art music or jazz; in more recent years the programs have turned back to a focus on musics considered to be traditionally and unproblematically "Turkish."

Audience participation was generally high at the observed concerts, but the type of participation varied, especially according to the type of music. At concerts of Turkish folk and popular music, we observed many people clapping, singing along, dancing, and even shouting out joyfully. At concerts of Turkish art and religious (tasavouf) music people cultivated a more contemplative bodily posture and interacted with each other through quiet verbal exchanges rather than by clapping or dancing together. European art music was more unpredictable in these respects. The two lower energy music types tended to engender an intimate setting, allowing for frequent impromptu dialogues between leading performers and members of the audience (typically men). Despite the negative ideas about women singing and dancing in Islamic culture, except at the concerts of religious music, women seemed to be more engaged than men in singing and moving to the performance.

Through theories about music and social life and about social capital, the vibrant scenes of the Üsküdar concerts can be evaluated as potential constructive social interventions on attendees' generalized and particularized trust perceptions, thick ties, social networks, and pro-social behaviors. These events were observed to be easily accessible and friendly spaces in which people with a variety of identities and cultural roots interacted and interrelated in diverse ways. People tended to come into some form of contact with both people already in their social networks and with strangers. Additionally, the program content of many of the Üsküdar municipal concerts contained clear messages about social cohesion. 


\section{General Methodology}

While controlled empirical designs can help to illuminate causal relations between individual variables, we aimed to make our analysis at the level of realworld, holistic experience. Instead of causes we looked for mechanisms specific to the contexts of Istanbul and the Üsküdar concert stages through which social capital would be constituted and subjected to changes. ${ }^{27} \mathrm{~A}$ concert is a complex event in which multiple perspectives arise - and music is a polysemic mediumso it was advantageous to take a pragmatic, multi-strategy approach that included quantitative and qualitative elements. The main researcher was a non-Turkish musicologist, who was always accompanied by a Turkish assistant. After each concert the two participated in a self-reflexive debriefing conversation, where individual observations were put into dialogue.

The most systematic component of the research was a survey about demographics, social network traits, and the relational and perceptual social experience at the concert. ${ }^{28}$ Many of the questions were modeled off of the 2011 World Values Survey for Turkey so that comparisons could be made to those findings. We tried to distribute the surveys approximately evenly across four adult age categories, the two normative genders, and women with and without the Islamic head covering. Most of the samples at each of the 15 concerts were representative according to these criteria. Participants could answer questions 1-14 at any time, but could only complete the remaining questions about perceptions and meetings during the concert upon exiting the hall. People were most open to completing the surveys when a native Turkish speaker distributed and explained the surveys to them individually before the concert, a detail that highlights how warm, oneon-one interactions underpin transactions in Turkish society.

As pilot survey attempts showed that few respondents could verbalize in detail about their feelings during the concert, data on affective states was largely gleaned through semi-participant observation, including observation of the researchers' personal experiences. We took special note of instances of cooperative movement and singing, which can positively influence pro-social behavior and social bonding. ${ }^{29}$ Enthusiastic verbal and non-verbal signs of appreciation for the performers, the amount of conversation taking place within the audience, and signs of boredom were also recorded. Pro-social messages in concert content were also, to a lesser degree, taken into consideration.

${ }^{27}$ Colin Robson and Kieran McCartan, Real World Research, $4^{\text {th }}$ edition (London: Wiley, 2015), 33-36.

${ }_{28}$ The complete survey can be viewed at https://janeharrison.me/istanbul-municipal-concerts-survey/

29 Rabinowitch, "Synchronization," 89; Patrick Juslin, "From everyday emotions to aesthetic emotions: towards a unified theory of musical emotions," Physics of Life Reviews 10, no. 3 (2013): 241-243. 


\section{Results}

\subsection{Audience Demographics}

Table 1. Descriptive Statistics for All Survey Questions

\begin{tabular}{|c|c|c|c|c|}
\hline Question Description & Responses & Prop. & Mean & SD \\
\hline \multirow[t]{4}{*}{ 1. Location of residence } & Üsküdar & .474 & & \\
\hline & Kadıköy & 154 & & \\
\hline & Istanbul other district & 335 & & \\
\hline & outside Istanbul & .031 & & \\
\hline \multirow[t]{3}{*}{ 2. Perceived similarity to neighbors } & very similar & .315 & & \\
\hline & somewhat similar & .391 & & \\
\hline & different & .293 & & \\
\hline \multirow[t]{8}{*}{ 3. Active organization memberships } & sport & 101 & & \\
\hline & adult educational classes & .235 & & \\
\hline & union & .068 & & \\
\hline & political party & .056 & & \\
\hline & professional & .153 & & \\
\hline & charity/environmental & 127 & & \\
\hline & religious & .070 & & \\
\hline & other & .061 & & \\
\hline 4. Total number of org. memberships & & & .891 & 1.0 \\
\hline 5. Working outside the home & & .602 & & \\
\hline \multicolumn{2}{|c|}{ 6. Social network breadth: bill pay question, yes } & .357 & & \\
\hline \multirow{3}{*}{$\begin{array}{l}\text { 7. Implicit religiousness (ranking of } \\
\text { religion, family, and Declaration of } \\
\text { Human Rights as values sources) }\end{array}$} & religion first & .379 & & \\
\hline & family first & .352 & & \\
\hline & human rights first & 270 & & \\
\hline \multirow{6}{*}{$\begin{array}{l}\text { 8. "With whom did you come to the } \\
\text { concert?" }\end{array}$} & family & .404 & & \\
\hline & friends & .359 & & \\
\hline & colleagues & .029 & & \\
\hline & religious organization & 0 & & \\
\hline & political organization & 0 & & \\
\hline & came alone & .210 & & \\
\hline \multicolumn{2}{|c|}{ 9. Üsküdar concert frequency (scale 1-6, low-high) } & & 3.67 & 1.61 \\
\hline \multicolumn{2}{|c|}{ 10. Istanbul-wide concert freq. (scale $0-6$, low-high) } & & 3.54 & 1.32 \\
\hline
\end{tabular}




\begin{tabular}{|c|c|c|c|c|}
\hline \multirow[t]{4}{*}{ 11. Age group } & $18-25$ & .213 & & \\
\hline & $26-40$ & .225 & & \\
\hline & $41-65$ & .543 & & \\
\hline & $65+$ & .108 & & \\
\hline \multirow[t]{3}{*}{ 12. Education level } & high school or less & .262 & & \\
\hline & university & 567 & & \\
\hline & graduate & .171 & & \\
\hline \multirow[t]{5}{*}{ 13. Monthly salary (Turkish Lira) } & 1,000 or less & .180 & & \\
\hline & $1,000-2,000$ & .237 & & \\
\hline & $2,000-3,000$ & .216 & & \\
\hline & $3,000-4,000$ & .142 & & \\
\hline & 4,000 or higher & .224 & & \\
\hline \multirow[t]{2}{*}{ 14. Gender } & female & .568 & & \\
\hline & male & .432 & & \\
\hline \multirow{5}{*}{$\begin{array}{l}\text { 15. Closeness to co-attendees during } \\
\text { concert }\end{array}$} & very close & .410 & & \\
\hline & close & .335 & & \\
\hline & not very close & .029 & & \\
\hline & not at all close & .010 & & \\
\hline & no change & .217 & & \\
\hline \multirow{5}{*}{$\begin{array}{l}\text { 16. Closeness to whole audience } \\
\text { during concert }\end{array}$} & very close & .152 & & \\
\hline & close & .465 & & \\
\hline & not very close & .125 & & \\
\hline & not at all close & .039 & & \\
\hline & no change & .219 & & \\
\hline \multicolumn{2}{|c|}{ 17. Trust in Üsküdar government (scale 1-4, low-high) } & & 3.18 & .404 \\
\hline \multirow[t]{7}{*}{ 18. People met at the concert } & neighbors & .056 & & \\
\hline & friends & .287 & & \\
\hline & family & .045 & & \\
\hline & work friends & .051 & & \\
\hline & organization members & .085 & & \\
\hline & totally new person & .138 & & \\
\hline & no one & .423 & & \\
\hline
\end{tabular}

*Total number of surveys collected was 429 , but for each question the number of NAs varied. Calculations in Table 1 and elsewhere exclude NAs. 
Concerts are special experiences that are shared by everyone in the room. More concretely, behaviors like clapping and singing along in unison create, at least temporarily, a meaningful social structure that entrains and unites large portions of strangers in the audience. The fact that such moments were frequent at the Üsküdar concerts is already a significant observation, but we can also look more deeply into the survey results to see what sorts of people tended to be caught up in these unifying and emotionally salient behaviors. First, we can look at the nature of people's social networks to see if they generally had small, homogenous networks that could use some expansion or larger, heterogeneous ones on which interactions at the concerts might have less of an impact. Around $60 \%$ of people were working outside of their homes (69\% of men versus $54 \%$ of women). The "bill pay" question was based on a question that Fidrmuc and Gerxhani used to assess breadth of social network. ${ }^{30}$ Just $36 \%$ of survey takers knew a non-family member, whom they could ask to help pay an emergency bill, suggesting a centering of social networks on family. ${ }^{31}$ However, this question was answered differently according to age, with a consistent decrease in proportion of those answering "yes" across the 4 age categories (54\%, 48\%, 27\%, $14 \%)$. Based on the review of literature, attendees' neighborhoods were assumed to be meaningful parts of their social networks. They were then essentially asked how much diversity they experienced in that social structure; as shown in the table, responses were distributed relatively evenly across the three ordinal levels of perceived similarity to one's neighbors. Forty-four percent of those surveyed were active in at least one civic organization, with considerably higher participation in Putnam versus Olson groups. This contrasts to the emphasis on Olson groups in Turkey in Fidrmuc and Gerxhani’s data, suggesting that Üsküdar concert attendees were socially distinctive as compared to a typical Turkish citizen. Audience members were generally more active than the national averages in all organizational categories listed on WVS 2011, but taken by themselves these numbers were not strikingly high.

Assessing the level of diversity among attendees is important, since it likely constrains the potential for expansion of generalized trust: there is a qualitative difference between having a positive experience with people who seem familiar versus different from oneself. Demographic diversity can also help to add greater heterophily to social networks. As the descriptive statistics in Table 1 show, across both genders, audiences generally consisted of well-educated, middle-aged

${ }^{30}$ Fidrmuc and Gërxhani, "Mind the gap!" 271.

31 This percentage is lower than the one reported by Fidrmuc and Gerxhani, but they used the more restrictive word "household" rather than "family," so a direct comparison cannot be made. 
people. Compared to the Üsküdar average of around $21 \%,{ }^{32} 83.8 \%$ of survey takers had a college degree. As in other parts of the world, Istanbul residents with lower education levels tend to show lower trust of their fellow citizens, ${ }^{33}$ suggesting that these attendees would tend to exhibit higher generalized trust. That might make for more fruitful interactions among strangers, but it also means that the residents who could really benefit from exposure to new people and cultural experiences were not being engaged well. Regarding other demographic variables the audience was quite diverse, including income levels (Q13) and geographical ancestry (memleket; not shown in Table 1). In Turkey, many women are especially cloistered within the home, with less educational and non-family socialization opportunities, and correspondingly smaller social networks and weaker generalized trust than men. ${ }^{34}$ In light of those findings, we were happy to see from manual counts that all the concert audiences contained at least as many women as men; women were often more willing to take our surveys as well. While we could not ask direct questions about religiousness, there was a consistent presence of high numbers of both women in conservative Islamic dress and those who were not at concerts of folk and religious music. Contrastingly, most women at European and Turkish art music concerts dressed in Western styles. Question 7 also tried to indirectly measure sense of religiousness by asking individuals to rank sources of their personal values in a forced-choice procedure. To simplify results, Table 1 only shows percentages for the ranking of a source as first among the three; it can be seen that no one source was strongly dominant among them. In terms of an intervention on social capital, the ideal situation would be people predicted to have low social activity outside of family coming into contact with a highly diverse mix of strangers. While this ideal was not being achieved according to all demographic measures, many Istanbul residents whose civic participation was certainly not high were coming into a space with many people quite different and probably unfamiliar to them. It is also true that even people that already possess high social capital of either type need continued contact with mechanisms that engender them to maintain those forms of capital.

\subsection{Co-attendance Units at the Concerts}

Concerning relational social capital, the vast majority of attendees used the concerts as opportunities to strengthen their pre-existing thick ties with family and friends. Consistent with the importance of family life in Turkey, Table 1 shows

\footnotetext{
32 Türkiye İstatistik Kurumu, "Seçilmiş Göstergelerle İstanbul 2013 (Istanbul: Türkiye İstatistik Kurumu, 2013), 111.

${ }^{33}$ Secor and O'Loughlin, "Social and political trust," 76.

${ }^{34}$ Ibid., 77; Ökten, “Aşiret,” 105.
} 
that people most commonly came to the concert with family members, although "friends" does not lag far behind. By contrast, very few people reported coming with people they knew from work or an organization, which involve particularized trust and ties; they were in fact much more likely to come alone. Those attending with family showed signs of having social networks or value systems that also emphasized family. There was a significant dependence in a Chi-Squared test $\left(X^{2}(3, \mathrm{~N}=412)=10.33, \mathrm{p}<.05\right)$ between the $\mathrm{Q} 8$ response and the bill-pay question assessing breadth of network outside of family; people who answered "no" to that question were 1.94 times more likely to come with family than those who answered "yes." Attendees who ranked family as the main source of their values came with family $52 \%$ of the time and came alone only $14 \%$ of the time; both of those counts showed large standardized residuals in a significant Chi-Squared test $\left(X^{2}(6, \mathrm{~N}=330)=17.10, \mathrm{p}<.01\right)$ for the co-attendance and values source questions. Women were not more likely to come with family members than men (41\% versus 39\%); many previous studies suggest that whether women are more constrained from socializing outside of the family is related to their education levels, and these audiences were generally highly educated..$^{35}$ A Mantel-Haensel Test of conditional independence further suggested that education level is a confound for gender and attendance with family $(\mathrm{M} 2(3, \mathrm{~N}=405)=11.22$, $\mathrm{p}<.01)$; more data for people with lower education levels is needed to better substantiate this situation.

\subsection{Meetings at the Concerts}

Given the diversity of strangers mixing in the audiences, and with music known to act as a kind of social bonding medium, the Üsküdar municipal concerts have the potential to function as good "low intensity meeting spaces." ${ }^{6}$ That potential can be evaluated by looking at data on the meetings that actually occurred there. Of the people we surveyed, 52\% had an impromptu, meaningful exchange with someone they already knew but had not come with. As shown in Table 1, most of the time these meetings involved friends, and based on participant observation and discussions with attendees, many of them were taking place among friends and family of the performers. They typically sat together near the stage and participated in the musical experience with notable enthusiasm. Impressively, 14\% of survey takers met an entirely new person at the concerts. We phrased this question carefully, using the Turkish word tanısmak, which means to make the acquaintance of someone; thus this $14 \%$ figure refers to meetings in which some

${ }^{35}$ Diane Sunar and Güler Okman-Fişek, "Contemporary Turkish families," in Families in Global Perspective, ed. U. Gielen and J. Roopnarine (Boston: Allyn \& Bacon/Pearson, 2005), 9, 20-23.

${ }^{36}$ Svanhild Aabø et al., "How do public libraries function as meeting places?" Library and Information Science Research 32, no. 1 (2010): 17. 
degree of personal information was exchanged and not merely cursory exchanges such as buying refreshments or saying "excuse me" while navigating through the seats. Taking place at night when the cultural centers were mostly empty, nearly all of these meetings would have involved audience members or perhaps performers rather than employees or people with other business in the building.

Table 2 shows three different binomial logistic regression models for meetings between people who already knew each other. ${ }^{37}$ Demographic variables alone, utilized as a control model, are not good predictors. Due to the relatively small sample size of answers for the meetings question, we had to be careful not to overload the model with variables, so we constructed two different additional models that used different subsets. In terms of the general social profile added into the second model, there are some significant effects for working outside the home (positive) and neighborhood diversity (negative for the middle category). The model that combines demographic variables with variables attached to the specific concert experience performs better than the other two and also better than the same model with the significant social variables added in (that model is not shown). Many aspects of an individual's concert experience seem to correlate with coming across people in their pre-existing social network: who they arrive with, the concert location, general frequency of attendance in Üsküdar, and type of music. Coming with family members, the reference category for the co-attendance question seemed to close off the social experience as compared to coming alone and especially coming with friends. The significant $\mathrm{p}$-values for all music types highlight how specific musical genres can have very real social meanings. Compared to the reference of Turkish folk music, all the other music types have a negative effect on meeting non-strangers, with that of Turkish art music being particularly strong. Causality can go in either direction, of course: the musical experience afforded by a genre might influence how people behave, or people with certain traits might be more drawn to particular genres. It is also shown that in comparison to the Altunizade location, significantly less impromptu interactions within social networks were occurring at Bağlarbaşı. One might expect the opposite, since the much larger Bağlarbaşı brings together greater numbers of people; this finding will be further evaluated in the discussion section.

${ }^{37}$ In these and other regression models, incomplete cases were removed. 
Table 2. Binomial GLM Regression Models for Meetings Among Known People

\begin{tabular}{|c|c|c|c|}
\hline Explanatory variables & Model A & Model B & Model C \\
\hline Intercept & $\begin{array}{l}1.89 \\
(.90)\end{array}$ & $\begin{array}{l}1.62 \\
(.93)\end{array}$ & $\begin{array}{c}1.83 \\
(1.45)\end{array}$ \\
\hline Gender (female) & $\begin{array}{l}1.13 \\
(.24)\end{array}$ & $\begin{array}{l}1.14 \\
(.25)\end{array}$ & $\begin{array}{c}.84 \\
(.32)\end{array}$ \\
\hline Education level & $\begin{array}{l}.80 \\
(.16)\end{array}$ & $\begin{array}{l}.80 \\
(.17)\end{array}$ & $\begin{array}{l}.86 \\
(.22)\end{array}$ \\
\hline Age $26-40$ (ref = 18-25) & $\begin{array}{l}1.24 \\
(.33)\end{array}$ & $\begin{array}{l}1.32 \\
(.37)\end{array}$ & $\begin{array}{l}1.37 \\
(.48)\end{array}$ \\
\hline Age 41-65 & $\begin{array}{l}.70 \\
(.29)\end{array}$ & $\begin{array}{l}.74 \\
(.31)\end{array}$ & $\begin{array}{l}.65 \\
(.37)\end{array}$ \\
\hline Age 65+ & $\begin{array}{c}.89 \\
(.22)\end{array}$ & $\begin{array}{c}.88 \\
(.23)\end{array}$ & $\begin{array}{c}.88 \\
(.28)\end{array}$ \\
\hline Income & $\begin{array}{l}.98 \\
(.10)\end{array}$ & $\begin{array}{l}.88 \\
(.11)\end{array}$ & $\begin{array}{l}1.05 \\
(.13)\end{array}$ \\
\hline n org. memberships & & $\begin{array}{l}1.17 \\
(.13)\end{array}$ & \\
\hline Bill pay question (yes) & & $\begin{array}{c}.89 \\
(.27)\end{array}$ & \\
\hline Working outside home & & $\begin{array}{l}1.70^{*} \\
(.30)\end{array}$ & \\
\hline $\begin{array}{l}\text { Neighbors somewhat like me } \\
\text { (ref = very similar) }\end{array}$ & & $\begin{array}{l}.63^{* *} \\
(.23)\end{array}$ & \\
\hline Neighbors different from me & & $\begin{array}{l}1.23 \\
(.21) \\
\end{array}$ & \\
\hline Venue (Bağlarbaşı) & & & $\begin{array}{l}.35^{* *} \\
(.52)\end{array}$ \\
\hline Üsküdar concert att. freq. & & & $\begin{array}{c}1.27^{* *} \\
(.10)\end{array}$ \\
\hline $\begin{array}{l}\text { Music type tasavvuf (ref = Turkish } \\
\text { folk) }\end{array}$ & & & $\begin{array}{l}.36^{*} \\
(.56)\end{array}$ \\
\hline Turkish art & & & $\begin{array}{l}.12 * * * \\
(.64)\end{array}$ \\
\hline European art & & & $\begin{array}{l}.42^{*} \\
(.47)\end{array}$ \\
\hline Came with friends (ref = family) & & & $\begin{array}{c}2.02 * * \\
(.33)\end{array}$ \\
\hline co-workers & & & $\begin{array}{l}.75 \\
(.73)\end{array}$ \\
\hline
\end{tabular}




\begin{tabular}{|c|c|c|c|}
\hline alone & & & $\begin{array}{l}1.23 \\
(.46)\end{array}$ \\
\hline $\begin{array}{l}\text { Positive feeling towards co-atten- } \\
\text { dees }\end{array}$ & & & $\begin{array}{l}1.30 \\
(.38)\end{array}$ \\
\hline $\begin{array}{l}\text { Positive feelings towards whole } \\
\text { audience }\end{array}$ & & & $\begin{array}{l}1.57 \\
(.34)\end{array}$ \\
\hline $\mathrm{n}$ & 318 & 306 & 241 \\
\hline residual deviance & 424.94 & 397.74 & 294.38 \\
\hline AIC & 438.94 & 421.74 & 328.38 \\
\hline R2 & .13 & 19 & .41 \\
\hline
\end{tabular}

$* \mathrm{p} \leq .10, * * \mathrm{p} \leq .05, * * * \mathrm{p} \leq .01, * * * * \mathrm{p} \leq .001$

In contrast to meetings among people who already knew each other, varied attempts to model meetings with new people produced no significant variables except a persistent, small, significant effect for the oldest age category. Perhaps the modest number of people reporting new meetings - $14 \%$ of all cases - made that variable difficult to model. Or, meeting new people could relate strongly to variables that fell outside of the survey questions or to an especially complex relationship among certain variables. Regardless, $14 \%$ was a higher number of first-time meetings than we expected, and according to that value alone it is safe to say that the concerts were having tangible, positive effects on social structure.

\subsection{Closeness Within the Audience}

Scholars have noted that trust is difficult to conceptualize and therefore to consistently measure. ${ }^{38}$ The most common methods are to observe people's behavior in an experimental trust game or to ask people to self-report about how trusting they are. Both methods lacked the ecological validity to which we were committed: how would an abstract question about "trust in most people" or a game involving something like exchanging money relate to micro-mechanisms operating in the concert experience? In addition, although running a game had certain advantages, it was not practically feasible. So then, what simple question on the survey could be relevant to both the concert context and the social capital mechanism of trust? Asking about feeling of closeness to co-attendees (a transformation of particularized trust) and to the entire audience (a transformation of generalized trust) was in line with previous research about music and social outcomes, with the idea being that closeness felt towards certain segments of the

${ }^{38}$ Edward Glaeser, David Laibson, Jose Scheinkman, and Christine Soutter, "Measuring trust," The Quarterly Journal of Economics 115, no. 3 (2000): 814. 
audience is an affective perception with sociological associations. Feeling close to one's family member in the next seat might strengthen feelings of trust in that person, and a general feeling of closeness to strangers in the audience might influence someone to feel closer to and more cooperative with strangers in her daily life. Even if closeness and trusting behavior do not strongly relate, it seems reasonable that such positive feelings by themselves are significant foundations for relational and even system capital, as people would probably be more inclined to help someone to whom they feel a sense of connection.

Respondents answered the two closeness survey questions directly after the concert, with a majority answering both positively. As a loose comparison to evaluate the survey results, we can look at the $62 \%$ positive response rate for generalized closeness at the concerts against the only $22 \%$ positive response rate to the question that asked Turkish citizens how much they trusted people they met for the first time on WVS 2011. As we might expect for society in Turkey, concerts seemed to do more for particularized and thick tie relationships than system-level social capital. While $41 \%$ of respondents felt "very close" to people they had come with, who were mostly friends and family members, only $15 \%$ inclined to say this about the entire audience.

That relatively high rate of warm feelings within the audience shows the potential of the Üsküdar concerts to impinge productively on social capital, but the nature of associations among the closeness variables and other variables needs to be made more precise. People's responses on the two closeness questions matched $50 \%$ of the time, suggesting that a more general disposition to feel close to others or not is being activated at the concerts, bringing this research on music and social capital in line with recent research about music and empathy. Feeling close to strangers was of greater interest as a beneficial social capital outcome than closeness to co-attendees, so it was explored with the same modeling process as that for the meetings variable. As can be seen in Table 3, demographic variables alone do not offer a good explanation for why certain people felt distant, close, or very close to others. The model that adds in stable social characteristics does a bit better but is clearly outshined by a third model that combines demographic and concert experience variables. This comparison suggests that while a dispositional trait such as empathy might be operating, it varies notably according to the specific characteristics of the concert experience. In particular, the significant, positive coefficient for municipal concert attendance frequency overlaps with multiple experimental findings reviewed by Rabinowitch that the biggest gains in dispositional empathy occur gradually as someone participates in a repeated musical activity. ${ }^{39}$ In terms of a theory of music and empathy proposed

${ }^{99}$ Rabinowitch, "Synchronization," 91. 
by Clarke, Vuokoski, and DeNora, feeling of closeness might build as people learn a certain mental script that is grounded in the particularities of the concerts and helps them to cooperatively create "a unified auditory scene that elicits the radical integration that is experienced as merged subjectivity." ${ }^{40}$ Likewise, Ahn and Odstrom suggest that people learn to trust as they are repeatedly exposed to others within a stable, highly structured context like a game. ${ }^{41} \mathrm{On}$ this point, closeness to co-attendees (Q15) shows an important distinction, as a variety of statistical tests and models did not show any relationship between it and concert attendance frequency.

The significance of the negative coefficient for the tasavouf music type overlaps with research about the evolutionary basis of music's impact on empathy. Endogenous opioids, socially beneficial neurochemicals, are released at elevated levels when people engage in entrained, physically exerting movements, including dancing and body-engaging forms of music making. ${ }^{42}$ Concordantly, people attending concerts of religious music, where we observed noticeably less bodily movements like clapping and dancing in one's seat, are predicted by Model C to be about half as likely as attendees of Turkish folk music concerts to feel close to strangers around them; with the folk music concerts being where we noticed the greatest gross bodily interaction with the musical performance. Although not statistically significant, the coefficient for the typically solemn and restrained Turkish art music audiences is similar to that of tasavouf music. Putting together the survey and semi-participant observation results, it seems that for social perceptions, bodily movement to the music mattered.

Table 3. Binomial GLM Regression of Closeness to the Whole Audience (Q16)

\begin{tabular}{|l|c|c|c|}
\hline & \multicolumn{3}{|c|}{ Q16 positive response ("close" or "very close") } \\
\hline Explanatory variables & Model A & Model B & Model C \\
\hline Intercept & 1.36 & 1.11 & .30 \\
& $(.95)$ & $(.98)$ & $(1.18)$ \\
\hline Gender (being female) & 1.02 & 1.00 & .86 \\
& $(.25)$ & $(.27)$ & $(.28)$ \\
\hline Education level & 1.05 & 1.12 & 1.15 \\
& $(.05)$ & $(.18)$ & $(.20)$ \\
\hline Age 26-40 (ref = 18-25) & $2.24^{* *}$ & $2.57^{* *}$ & .95 \\
& $(.36)$ & $(.39)$ & $(.43)$ \\
\hline
\end{tabular}

${ }^{40}$ Clarke et al., "Music, empathy," 68.

${ }^{41}$ T. K. Ahn and Elinor Ostrom, "Social capital and collective action," in The Handbook of Social Capital, ed. D. Castiglione, J. Van Deth, and G. Wolleb, 70-100 (Oxford: Oxford University Press, 2008).

${ }^{42}$ Rabinowitch, "Synchronization," 92. 


\begin{tabular}{|c|c|c|c|}
\hline Age 41-65 & $\begin{array}{l}1.35 \\
(.32)\end{array}$ & $\begin{array}{l}1.33 \\
(.33)\end{array}$ & $\begin{array}{l}1.32 \\
(.41)\end{array}$ \\
\hline Age 65+ & $\begin{array}{l}1.05 \\
(.23)\end{array}$ & $\begin{array}{l}97 \\
(.24)\end{array}$ & $\begin{array}{l}2.36 \\
(.62)\end{array}$ \\
\hline Income & $\begin{array}{l}1.04 \\
(.04)\end{array}$ & $\begin{array}{l}.94 \\
(.12)\end{array}$ & $\begin{array}{l}1.12 \\
(.12)\end{array}$ \\
\hline n org. memberships & & $\begin{array}{l}1.05 \\
(.13)\end{array}$ & \\
\hline Bill pay question (yes) & & $\begin{array}{l}1.08 \\
(.28)\end{array}$ & \\
\hline Working outside home & & $\begin{array}{l}1.33 \\
(.30)\end{array}$ & \\
\hline $\begin{array}{l}\text { Neighbors somewhat like me (ref = } \\
\text { very similar) }\end{array}$ & & $\begin{array}{l}.73 \\
(.24)\end{array}$ & \\
\hline Neighbors different from me & & $\begin{array}{c}1.71^{* *} \\
(.21)\end{array}$ & \\
\hline Üsküdar concert att. freq. & & & $\begin{array}{c}1.31^{* * *} \\
(.09)\end{array}$ \\
\hline $\begin{array}{l}\text { Music Type tasavvuf (ref = Turkish } \\
\text { folk) }\end{array}$ & & & $\begin{array}{l}.43 * * \\
(.36)\end{array}$ \\
\hline Turkish art & & & $\begin{array}{l}.53 \\
(.39)\end{array}$ \\
\hline European art & & & $\begin{array}{l}1.07 \\
(.44)\end{array}$ \\
\hline Met someone at concert & & & $\begin{array}{l}1.23 \\
(.28)\end{array}$ \\
\hline Came alone & & & $\begin{array}{l}1.19 \\
(.32)\end{array}$ \\
\hline $\mathrm{n}$ & 315 & 297 & 284 \\
\hline residual deviance & 399.35 & 367.16 & 341.68 \\
\hline AIC & 413.35 & 391.16 & 367.68 \\
\hline R2 & .15 & .22 & .28 \\
\hline
\end{tabular}

${ }^{*} p \leq .10, * * p \leq .05, * * * p \leq .01, * * * * p \leq .001$

While not an experimental study, it is interesting that our results replicate a few patterns being consistently observed for music and empathy. At the same time, the picture of closeness to strangers at the Üsküdar concerts contains novel details, such as the significant positive coefficient in Table 3 for having neighbors who are "very different" from the survey taker. Also, any potential dispositional trait that the closeness questions tap into varies according to whether one is 
being asked about feelings towards people they already know well or strangers, as stated previously. Clarke et al. are careful to define dispositional empathy as a potential for behavior that is variably expressed because it is grounded in "person-environment complementary;" 33 in a similar way, feeling of closeness has been shown to vary according to factors related to the relationship targeted by that feeling, people's general social experiences, people's familiarity with a certain context, and genre characteristics.

\section{General Discussion}

Examination of several variables has given evidence that the Üsküdar municipal concerts were functioning as a context in which social capital was at play. Attendees were not simply sitting down, watching the stage performance, and then leaving; many of them were experiencing positive perceptions of the people around them and interacting with each other to no small degree as they took in the show. Regression analyses repeatedly implicated concert experience variables, especially type of music and frequency of attending concerts, in stronger relationships with all of our social capital mechanism variables than demographics or stable social characteristics. While causality cannot be discussed, these regression models are consistent with the contention that live concert attendances can function as positive interventions on social capital. Furthermore, we show evidence that this might be occurring on multiple forms and mechanisms of social capital, encompassing both relational and system capital. Demographic and stable social variables seemed to constrain the relationships among the groups of people attending together, but for both impromptu meetings and perceptions towards strangers, variables that operationalized people's experience at the specific concert had more of an impact. That is a hopeful result, because it suggests that a person's interactions with others is not very dependent on what she is like before stepping into the hall or even the group of people with whom she arrived. The concerts functioned as a medium that flexibly facilitated a wide variety of experiences that can be useful to different kinds of people in different ways. Their existing close social networks were being sustained, they were meeting new people that might be added to those networks, and they were coming into contact with a variety of strangers and having positive perceptions of them.

Since entry into the event hall requires nothing more than walking through the door, nearly anyone could attend concerts at the Üsküdar cultural centers. The people who actually do attend, however, are a subset of the general Istanbul population who tend to be highly educated, not as dependent on thick tie social networks as the general data for Turkey anticipates, and modestly more

${ }^{43}$ Clarke et al., "Music, empathy," 68. 
involved in Putnam-style civic participation. Female attendees seemed to have less constraint on social mobility than other researchers have found for women in Turkey, perhaps being related to their high education levels. Statistical tests gave no reason to believe that the concert experience had a causal effect on these stable characteristics, and so the likely explanation is that a certain type of person is drawn to these concerts. Being elective and engendering a shared enjoyable experience in a truly public space, they might be functioning like the active civic engagement Putnam emphasizes and like the low intensity meeting spaces of some contemporary libraries. ${ }^{44}$ These concerts might even have an advantage over Putnam groups, because while Putnam groups tend to bring together similar people, ${ }^{45}$ the Üsküdar concert audiences were quite varied. If the municipality wished to improve the social efficacy of these concerts, it could try to attract people who, in terms of demographic and social profiles, could see stronger benefit to their social capital.

In terms of attendance patterns, the emphasis on family networks in the literature on Turkish society was confirmed, and there were significant interactions among friends as well. Indeed, given Turkish society's foundation in family, friend, and neighborhood networks, it might be more practical for the concerts to contribute to the health of people's relational capital rather than hoping for a radical increase in generalized trust. Our survey did not distinguish different types of friends in terms of co-attendees, so we do not know how often people were attending with neighbors. We did ask about chance meetings with neighbors, and those were quite low. The positive significance of increased neighborhood diversity in the regressions on meetings and generalized closeness suggest that the social habits grounded in people's neighborhood networks related to how they interacted with others at the concerts, which recalls Secor and O'Loughlin's emphasis on neighborhood as an important social structure in Istanbul. In contrast to that previous study, greater involvement outside of thick ties, through working outside of the home or participating in voluntary organizations, did not have significant effects on pro-social behavior at the concerts.

Although this analysis did not focus much on details of musical sound, the genre variable did shed some light on that dimension. Originating in the approach to programming by the Üsküdar municipality, most of the concerts fit clearly into one of only four genres. Because these genres have become quite conventionalized in Turkey, all of the concerts of the same genre were very similar in terms of general sound quality, ensemble size, social behavior of the performers,

${ }^{44}$ Aabø et al., "How do libraries," p. 17.

45 Eric Uslaner, "Trust as a moral value" in The Handbook of Social Capital, ed. D. Castiglione, J. Van Deth, and G. Wolleb, 101-121, (Oxford: Oxford University Press, 2008), 104. 
audience participation, and other factors. For meetings and closeness to strangers, genre was significant, and in a way consistent with the emphasis on physically active and entrained movement to music in previous studies about music, emotion, and empathy. The important role of genre in predicting attendees' social behavior according to these variables might be an extension of other scholars' findings that specific musical traits tend to pair with specific affective states. ${ }^{46} \mathrm{To}$ further test that hypothesis, it would be important to design controlled studies that could distinguish whether the effects seen for certain types of music on the social variables, especially the differences between higher and lower energetic genres, are more due to the music's action as a stimulus or a relationship among music preferences, personality, and other characteristics.

Besides entraining audience members to distinctive bodily states, genres afforded qualitative differences in the social environment. Turkish art and tasavvuf music audiences displayed greater focus on and communication with the performers. Smaller ensembles without conductors perform those musics, and there was often a dynamic, intimate communication among the players similar to European chamber ensembles. They spent more time in improvisatory modes and interacted personally with audience members during the show. The large ensembles of European art and Turkish folk concerts seemed more formalized and there was less of a sense of communication with the audience passing through the "forth wall" of the stage boundary. Since the more intimate genres were nearly always programmed at Altunizade cultural center, the points raised about genre then map onto geographical location of the hall. Beyond genre, Altunizade is simply a smaller space and it seemed to engender closer proximity among people than Bağlarbaşı. The significance of the venue variable for meetings among people who already knew each other, shown in Table 2, suggests that in at least one way the intimacy afforded by both the space and the behavior modeled by the performers at Altunizade relates to the nature of the social experiences among audience members there.

Semi-participant observations revealed that it would have been advantageous to ask about how audience members felt towards the performers, since many audience members seemed to know at least one of them. That relationship was probably quite influential on such people's entire concert experience, including how they perceived their relationship with various segments of the audience. Especially in the more intimate settings, some audience members sought a feeling of closeness with the musicians, even to the point of actively trying to speak with them during the concert. Some of these exchanges seemed like examples

${ }^{46}$ Tia DeNora, After Adorno: Rethinking Music Sociology (Cambridge: Cambridge University Press, 2003), 100-116. 
of "fan" behavior towards the performers rather than a personal relationship. It would be illuminating to probe fan mentalities among Üsküdar concert audiences, especially the possibility of feelings of solidarity between individuals who recognize each other as fans of the same musician.

This study was launched as a project about how music might strengthen democracy in Turkey. By engaging carefully with theories of social capital, our understanding of what a strong social fabric entails was broadened beyond simply generalized trust and civic mindedness. Analysis of our survey results provide evidence that the municipal concerts in Üsküdar, and perhaps by extension other districts in Istanbul, serve as vital reinforcing and innovating social forces that can indeed inform democratic processes and a wealth of other aspects of residents' social lives.

\section{Social Capital at Municipal Concerts in Istanbul}

\section{Abstract}

This study considered how music affects social capital within Istanbul's social fabric. Taking into account Istanbul's specific socio-cultural structure and research on the social outcomes of music participation, we developed a set of potential mechanisms through which personal social networks, thick ties, particularized ties and trust, and generalized trust might be affected by concert attendance at free concerts in the Istanbul district of Üsküdar. This article focuses on statistical analysis of audience survey results. The concerts proved to be lively social environments, and all types of social capital seemed to benefit from concert attendance, although outcomes depended especially on the genre of music.

\section{Sociální kapitál na městských koncertech v Istanbulu}

\section{Abstrakt}

Tato studie se zabývala tím, jak hudba ovlivňuje sociální kapitál v rámci istanbulské sociální struktury. Vzali jsme v potaz specifickou sociálně-kulturní strukturu Istanbulu a výzkum sociálních př́nosů hudby a vyvinuli jsme sadu potenciálních mechanismů, prostřednictvím kterých mohou být osobní sociální sítě, silné vazby, partikularizované vazby a důvěra a generalizovaná důvěra ovlivněny návštěvností volně př́stupných koncertů v istanbulském distriktu Üsküdar. Tento článek se zaměřuje na statistickou analýzu dat $\mathrm{z}$ dotazníků od publika. Potvrdilo se, že koncerty jsou sociálně čilá prostředí, a zdá se, že všechny typy sociálního 
kapitálu benefitovaly $z$ navštěvování koncertů, třebaže př́nosy závisely především na hudebním žánru.

\section{Keywords}

social capital; Istanbul; live concerts; affect; social networks; empathy

\section{Klíčová slova}

sociální kapitál; Istanbul; živé koncerty; citový stav; sociální sítě; empatie

Jane E. Harrison

Center for Advanced Studies in Music (MIAM)

Istanbul Technical University

jane.harrison39@gmail.com 